\title{
PEMETAAN KELAYAKAN LAHAN BUDIDAYA RUMPUT LAUT (Kappaphycus alvarezii) DI KABUPATEN BINTAN PROVINSI KEPULAUAN RIAU DENGAN PENDEKATAN SISTEM INFORMASI GEOGRAFIS DAN PENGINDERAAN JAUH
}

\author{
I Nyoman Radiarta", Adang Saputra ${ }^{* *}$, dan Hatim Albasri") \\ *) Pusat Penelitian dan Pengembangan Perikanan Budidaya \\ Jl. Ragunan 20, Pasar Minggu, Jakarta Selatan 12540 \\ E-mail: radiarta@yahoo.com \\ *) Balai Penelitian dan Pengembangan Budidaya Air Tawar \\ Jl. Sempur No. 1, Bogor 16154
}

(Naskah diterima: 12 September 2011; Disetujui publikasi: 3 Januari 2012)

\begin{abstract}
ABSTRAK
Rumput laut merupakan komoditas unggulan ekspor perikanan budidaya di Indonesia. Untuk mempertahankan ataupun meningkatkan produksinya dapat dilakukan melalui perluasan areal budidaya. Pemilihan lokasi yang sesuai merupakan tahapan awal untuk mendukung keberhasilan usaha budidaya rumput laut. Penelitian ini bertujuan untuk melakukan analisis kelayakan lahan untuk budidaya rumput laut dengan metode apung di kawasan minapolitan Kabupaten Bintan. Data kualitas perairan telah dikumpulkan saat survai lapangan bulan Juli 2010. ALOS AVNIR-2 digunakan untuk mengekstrak data sosial infrastruktur. Data kualitas perairan dan sosial infrastruktur kemudian dianalisis secara spasial dengan sistem informasi geografis dan multi criteria analysis. Hasil analisis spasial menunjukkan bahwa dari total potensial pengembangan $(904$ $\mathrm{km}^{2}$ ), sekitar $13 \%$ tergolong sangat layak untuk pengembangan budidaya rumput laut. Lokasi dengan kategori sangat layak terkonsentrasi di Pulau Mantang, Telang Kecil, Gin Besar, Numbing, Gin Kecil, Buton, Poto, dan Kelong. Hasil penelitian ini sangat relevan dengan penetapan Kabupaten Bintan, meliputi: Kecamatan Bintan Timur, Mantang, dan Bintan Pesisir, sebagai kawasan sentra pengembangan minapolitan.
\end{abstract}

KATA KUNCl: budidaya rumput laut, pemilihan lokasi, SIG, penginderaan jauh, Bintan

ABSTRACT: Mapping of suitability sites for seaweed (Kappaphycus alvarezii) aquaculture at Bintan District Riau Islands Province: geographic information system and satellite remote sensing approach. By: I Nyoman Radiarta, Adang Saputra, and Hatim Albasri

Seaweed is an important export aquaculture commodity in Indonesia. Expansion of aquaculture areas might be one step in order to sustain or even to increase seaweed production. To ensure long-term successfully of providing seaweed production, finding suitable sites is an important step in any aquaculture operation. This study was conducted to analyse suitable sites for seaweed aquaculture using long line technique in minapolitan area of Bintan District. Water quality data were collected during field survey in July 2010. ALOS AVNIR-2 data was used to extract socio infrastructure data. Water quality and socio infrastructure data were then analysed using geographic information system and multi criteria analysis. The results show that from $904 \mathrm{~km}^{2}$ 
potential area, only about $13 \%$ had the most suitable area for developing seaweed aquaculture. These areas were concentrated around Mantang, Talang Kecil, Gin Besar, Numbing, Gin Kecil, Buton, Poto, and Kelong Islands. The result from this study is relevant with selection of Bintan District, such as Bintan Timur, Mantang, and Bintan Pesisir Sub-districts, as central for minapolitan development areas.

\section{KEYWORDS: seaweed aquaculture, site selection, GIS, remote sensing, Bintan}

\section{PENDAHULUAN}

Rumput laut merupakan komoditas unggulan ekspor produk perikanan budidaya di Indonesia. Data statistik FAO (FAO Fisheries and Aquaculture Department, 2010) menunjukkan bahwa produksi rumput laut di Indonesia mengalami peningkatan yang sangat signifikan dari sekitar 205 ribu ton pada tahun 2000 menjadi sekitar 2 juta ton tahun 2008. Peningkatan produksi rumput laut tersebut masih terus diupayakan oleh pemerintah Indonesia melalui Kementerian Kelautan dan Perikanan. Dengan dicanangkannya program nasional minapolitan oleh Kementerian Kelautan dan Perikanan diharapkan dapat menggali dan memanfaatkan potensi perairan yang ada di masing-masing wilayah pengelolaan minapolitan guna mendukung peningkatan produksi perikanan budidaya.

Peningkatan aktivitas budidaya laut belakangan ini menjadi perhatian berbagai pihak khususnya masalah dampak yang ditimbulkan terhadap lingkungan perairan (Costa-Pierce, 2008). Dampak kegiatan budidaya harus diminimalkan atau bahkan dapat dihilangkan. Oleh sebab itu, segala kegiatan budidaya perikanan harus berwawasan lingkungan sehingga aktivitas budidaya perikanan tersebut dapat berkelanjutan (FAO, 2010). Pemilihan lokasi yang sesuai untuk budidaya laut merupakan salah satu tahapan awal yang harus dilakukan sehingga dalam pelaksanaannya tidak menimbulkan dampak yang serius terhadap lingkungan sekitarnya. Secara komprehensif beberapa faktor harus dipertimbangkan dalam pemilihan lokasi budidaya di antaranya faktor lingkungan (ekologi dan biologi), sosial ekonomi, dan fasilitas pendukung lainnya. Budidaya rumput laut, jika dilihat dari dampaknya terhadap penurunan mutu lingkungan, diyakini memiliki dampak yang sangat kecil dibandingkan dengan budidaya ikan (Zang et al., 2009). Bahkan belakangan ini rumput laut banyak dibudidayakan bersama dengan ikan guna meminimalkan dampak yang ditimbulkan oleh budidaya ikan tersebut atau dikenal dengan istilah integrated multi-trophic aquaculture (IMTA; Troell et al., 2009). Selain keunggulan dari aspek lingkungan, keunggulan budidaya rumput laut lainnya meliputi mudahnya teknologi budidaya yang diperlukan serta produk yang dihasilkan mempunyai kegunaan yang beragam.

Kabupaten Bintan merupakan kabupaten kepulauan dengan luas perairan lebih besar (98\%) dari daratannya (2\%), dan memiliki sekitar 202 pulau (Anonim, 2008). Pulau-pulau tersebut dikelilingi oleh perairan sehingga kawasan tersebut berpotensi untuk pengembangan budidaya laut. Potensi yang ada tersebut tentunya harus dikaji secara baik guna memberikan data dan informasi yang bermanfaat bagi pengembangan budidaya laut khususnya budidaya rumput laut di Kabupaten Bintan. Analisis secara spasial untuk perikanan budidaya yang berhubungan dengan pendekatan lingkungan secara komprehensif telah didokumentasikan (AguilarManjarrez et al., 2010). Sesuai dengan pendekatan lingkungan, analisis spasial berdasarkan luasan lokasi kajian terbagi menjadi tiga yaitu lokal (farm scale), regional (the watershed/aquaculture zone), dan global (wider regional and global scale). Sedangkan permasalahan yang umum dikaji dengan sistem informasi geografis (SIG) meliputi pengembangan perikanan budidaya, manajemen perikanan budidaya dan pengembangan multisektoral yang termasuk di dalamnya perikanan budidaya.

Penelitian ini bertujuan menganalisis tingkat kelayakan lahan untuk budidaya rumput laut (Kappaphycus alvarezii) dengan metode apung di lokasi minapolitan Kabupaten Bintan. Analisis kelayakan lahan dilakukan secara spasial dengan memadukan antara SIG dan multicriteria analisis. Hasil dari penelitian ini diharapkan dapat memberikan gambaran umum tingkat kelayakan lahan di Kabupaten 
Bintan sehubungan dengan penentuan lokasi tersebut sebagai kawasan pengembangan minapolitan.

\section{BAHAN DAN METODE}

Penelitian ini telah dilakukan di kawasan pengembangan minapolitan Kabupaten Bintan (0 47' LU; 104 37' BT, Gambar 1). Karakteristik perairan yang cukup terlindung dan relatif tenang sangat mendukung bagi pengembangan budidaya rumput laut yang merupakan komoditas utama pengembangan minapolitan di kabupaten ini.

Pengumpulan data kualitas perairan dilakukan pada bulan Juli 2010. Sebaran titik pengamatan dirancang secara acak sederhana (Morain, 1999) menggunakan SIG. Titik pengamatan disebar secara proposional sehingga dapat mewakili karakteristik perairan yang disurvai. Informasi tambahan dari dinas kelautan dan perikanan setempat juga digunakan sebagai dasar untuk menentukan lokasi titik pengamatan. Sebanyak 32 titik pengamatan telah berhasil dikumpulkan (Gambar 1). Pengambilan data lapangan dilakukan pada kisaran waktu pukul 09.00-16.00 WIB, dan kedalaman sekitar 0-3 m. Data penting yang berpengaruh terhadap pengembangan budidaya rumput laut telah dikumpulkan meliputi suhu perairan, salinitas, kedalaman, dan kecerahan perairan.

Selain data lapangan, data sekunder berupa peta dasar dan kedalaman perairan juga dikumpulkan. Pada penelitian ini, peta dasar diperoleh melalui proses digitasi secara on screen dari citra satelit Landsat 7 (path/row: 125/059) tanggal 28 April 2000 dan ALOS AVNIR-2 tanggal 13 Februari 2010. Tema utama dari peta dasar yang diambil meliputi: garis pantai, sungai, sebaran penduduk, kawasan industri, dan ekosistem pesisir (terumbu karang dan bakau). Data kedalaman didigitasi dari peta kedalaman perairan keluaran Dinas Hidro Oseanografi TNI-AL.

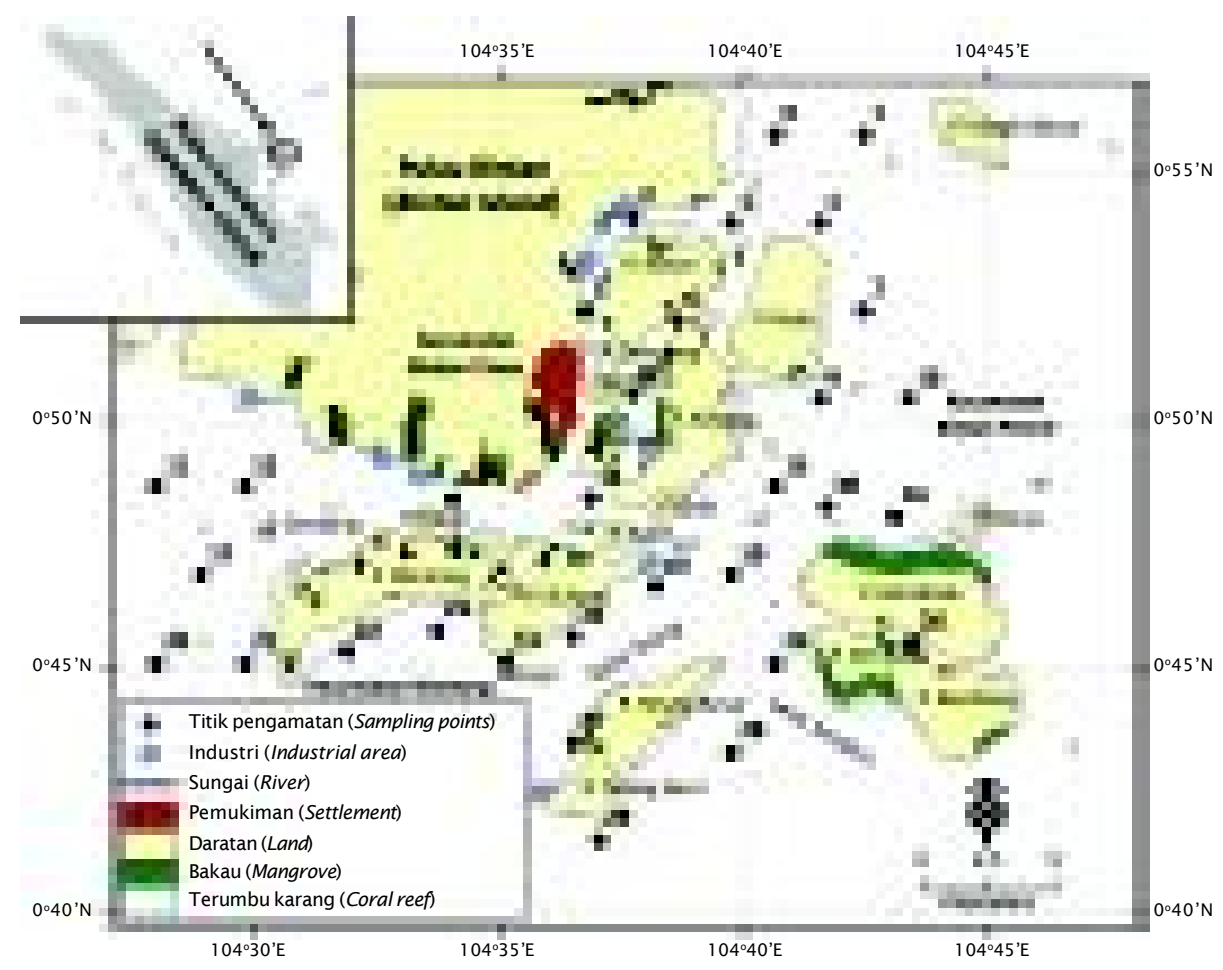

Gambar 1. Lokasi penelitian di Kabupaten Bintan Provinsi Kepulauan Riau dan sebaran titik pengamatan kualitas air

Figure 1. Study area in Bintan District Riau Island Province and distribution of water quality sampling position 


\section{Analisis Spasial Kelayakan Lahan}

Model kelayakan lahan untuk budidaya rumput laut di Kabupaten Bintan disusun berdasarkan model hirarki (Malczewski, 2000). Model hirarki membagi seluruh kriteria menjadi bagian yang lebih spesifik (parameter). Bagian utama hirarki adalah keluaran akhir (goal), kemudian terbagi menjadi bagian yang lebih kompleks meliputi submodel dan parameter (Gambar 2). Pada penelitian ini mengidentifikasi sebanyak tujuh parameter utama yang digunakan untuk analisis kelayakan lahan budidaya rumput laut. Parameter tersebut dikelompokkan baik sebagai faktor pendukung maupun pembatas (Nath et al., 2000) meliputi submodel kualitas perairan, sosialinfrastruktur, dan pembatas.

Data lapangan yang berupa titik pengamatan terlebih dahulu dikonversi menjadi data raster. Teknik interpolasi inverse distance weighted dan distance analysis Johnson \& McChow, 2001) yang terdapat dalam program ArcGIS v.9.3 (The Environmental System Research Institute (ESRI), USA) telah digunakan untuk mengkorvesikan data yang terkumpul, sehingga dapat digunakan dalam analisis spasial. Seluruh data yang digunakan harus mempunyai sistem skor yang sama. Oleh karena itu, tahapan manipulasi ataupun klasifikasi data sangat diperlukan untuk membuat suatu sistem skor yang sama. Penentuan skor untuk masing-masing parameter berdasarkan efek dari parameter tersebut bagi budidaya rumput laut (Kappaphycus alvarezii). Penelitian ini menggunakan skor 1-4 (Salam et al., 2005; Giap et al., 2005). Skor 4 adalah sangat layak, sedangkan 1 adalah tidak layak bagi kegiatan budidaya rumput laut (Tabel 1). Tingkat kelayakan lahan masing-masing parameter mengacu pada Tiensongrusmee (1990), Mubarak et al. (1990), Sulistijo \& Nontji (1995), dan Radiarta et al. (2008).

Langkah selanjutnya adalah menentukan bobot untuk masing-masing parameter. Parameter yang mempunyai pengaruh dominan dan relatif tidak dapat diubah memiliki faktor pembobot yang paling besar, sebaliknya parameter yang kurang dominan memiliki faktor pembobot yang lebih kecil. Meskipun terdapat beberapa teknik untuk pembobotan (Malczewski, 1999), penelitian ini mengunakan Analytical hierarchy process (AHP) yang dikenal dengan pair-wise comparison (Saaty, 1977; Malczewski, 1999) untuk menentukan bobot dari masing-masing parameter. Pada tahapan ini opini peneliti (expert opinions) dan studi pustaka digunakan sebagai dasar dalam pembobotan. Dalam metode pair-wise comparison, tingkat kepentingan dari masingmasing parameter dievaluasi berdasarkan 17

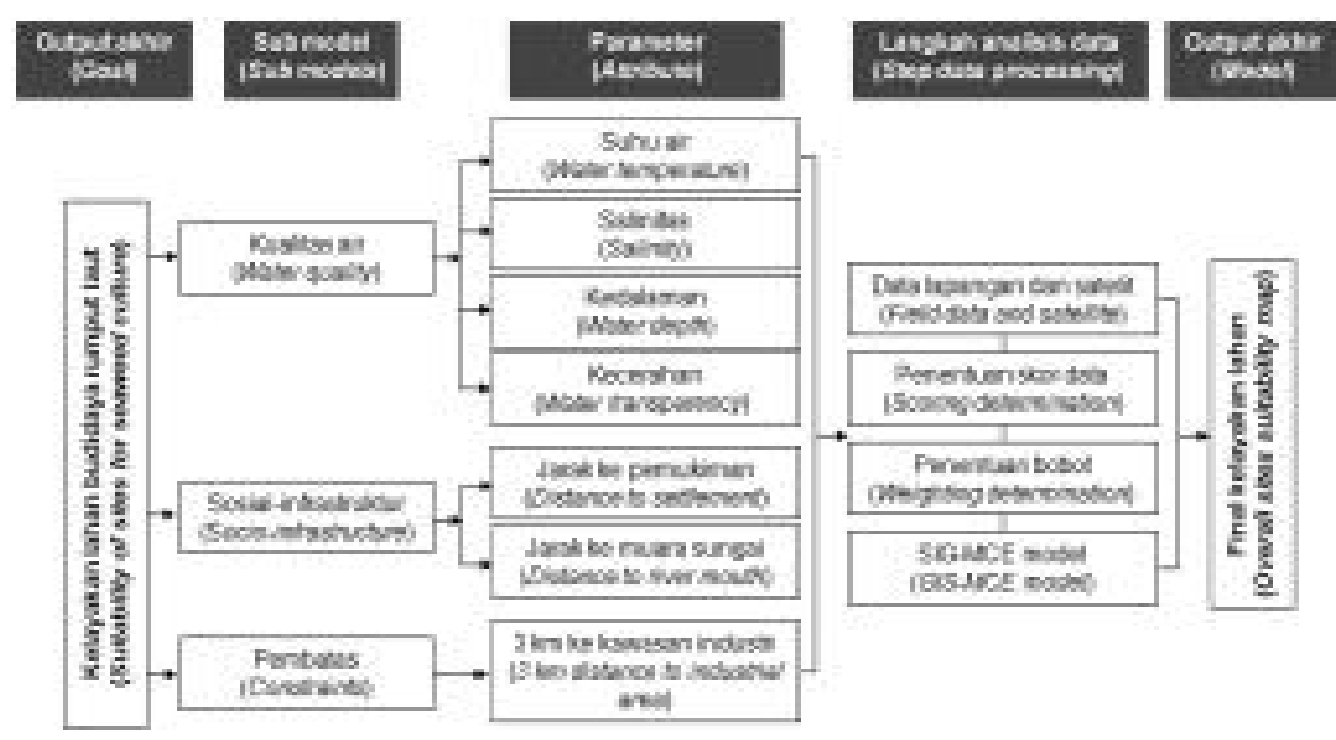

Gambar 2. Tahapan analisis kelayakan lahan untuk budidaya rumput laut di Kabupaten Bintan

Figure 2. Flowchart of site selection analyses for seaweed aquaculture in Bintan District 
Tabel 1. Tingkat kelayakan parameter kualitas perairan dan sosial-infrastruktur untuk budidaya rumput laut di Kabupaten Bintan

Table 1. Water quality and socio-infrastructure factors requirement and suitability scores for seaweed aquaculture in Bintan District

\begin{tabular}{|c|c|c|c|c|c|}
\hline $\begin{array}{c}\text { Peubah } \\
\text { Parameter }\end{array}$ & $\begin{array}{l}\text { Sat uan } \\
\text { Unit }\end{array}$ & $\begin{array}{l}\text { Sangat } \\
\text { layak } \\
\text { Most } \\
\text { suitable }\end{array}$ & $\begin{array}{l}\text { Layak } \\
\text { Suitable }\end{array}$ & $\begin{array}{c}\text { Cukup } \\
\text { layak } \\
\text { Marginally } \\
\text { suitable }\end{array}$ & $\begin{array}{c}\text { Tidak } \\
\text { layak } \\
\text { Not } \\
\text { suitable }\end{array}$ \\
\hline \multicolumn{6}{|c|}{ Kualitas perairan (Water quality) } \\
\hline $\begin{array}{l}\text { Kecerahan } \\
\text { Water transparency }\end{array}$ & $\mathrm{m}$ & $>=3$ & $2-3$ & $1-2$ & $<1$ \\
\hline $\begin{array}{l}\text { Kedalaman } \\
\text { Bathymetry }\end{array}$ & $\mathrm{m}$ & $3-10$ & $10-15 ; 2-3$ & $15-20$ & $<2 \&>20$ \\
\hline $\begin{array}{l}\text { Salinitas } \\
\text { Salinity }\end{array}$ & ppt & $32-34$ & $28-32$ & $25-28$ & $<25 \&>34$ \\
\hline $\begin{array}{l}\text { Suhu } \\
\text { Water temperature }\end{array}$ & ${ }^{\circ} \mathrm{C}$ & $28-30$ & $30-32 ; 27-28$ & $32-35$ & $<27 ;>35$ \\
\hline \multicolumn{6}{|l|}{$\begin{array}{l}\text { Sosial-infrastruktur (Socio- } \\
\text { infrastructure) }\end{array}$} \\
\hline $\begin{array}{l}\text { Jarak ke pemukiman } \\
\text { Distance to settlement } \\
\text { Jarak ke muara sungai } \\
\text { Distance to river mouth }\end{array}$ & $\mathrm{m}$ & $<4,000$ & $4,000-5,000$ & $5,000-7,000$ & $>7,000$ \\
\hline
\end{tabular}

skala dimulai dari yang tidak terlalu penting $(1 / 9,1 / 8,1 / 7, \ldots, 1 / 2)$ sampai ke yang sangat penting $(1,2,3, \ldots, 9)$. Setelah perbandingan dibuat, kemudian bobot dari matrik pair-wise comparison dihitung untuk menghasilkan total bobot sama dengan satu (1). Keunggulan menggunakan AHP adalah dapat menghitung rasio konsistensi dari distribusi bobot yang diperoleh. Rasio ini menggambarkan konsekuensi dari proses pembobotan dan menunjukkan probabilitas nilai yang ditentukan secara acak. Nilai rasio lebih kecil atau sama dengan 0,1 merupakan nilai yang dapat diterima dan menunjukkan penentuan nilai yang konsisten dalam proses pembobotan (Saaty, 1977; Banai-Kashani, 1989). Tabel 2 menyajikan proses pembobotan dari parameter kelayakan lahan budidaya rumput laut.

Setelah seluruh skor dan bobot dari spasial data telah ditentukan, langkah selanjutnya adalah melakukan analisis spasial menggunakan teknik multi-ceriteria evaluation yang dikenal dengan nama weighted linear combination (Malczewski, 1999) yang terdapat dalam pemodelan di ArcGIS versi 9.3 (The Environmental System Research Institute (ESRI), USA).

\section{HASIL DAN BAHASAN}

\section{Kondisi Umum Lokasi Penelitian}

Kabupaten Bintan telah ditetapkan sebagai kawasan minapolitan sesuai dengan surat keputusan Menteri Kelautan dan Perikanan Republik Indonesia Nomor KEP.32/ MEN/2010 tentang penetapan kawasan minapolitan di Indonesia. Implementasi dari keputusan tersebut, pemerintah daerah Kabupaten Bintan telah menetapkan tiga kecamatan sebagai sentra pengembangan kawasan minapolitan meliputi Kecamatan Bintan Timur, Mantang, dan Bintan Pesisir, dengan komoditas unggulan pengembangan adalah rumput laut. Dilihat dari karakteristik perairan dengan banyaknya pulau, teluk, dan selat, menjadikan kawasan ini sangat berpotensi bagi pengembangan budidaya laut. Budidaya laut telah cukup lama berkembang di Kabupaten Bintan terutama budidaya ikan 
Tabel 2. Matrik pair wise comparison untuk penentuan bobot dari masing-masing parameter/ submodel yang digunakan dalam analisis kelayakan lahan untuk budidaya rumput laut di Kabupaten Bintan

Table 2. Pair wise comparison matrix for assessing relative important weight of parameter/ sub-model for seaweed aquaculture site selection in Bintan District

\begin{tabular}{|c|c|c|c|c|c|}
\hline $\begin{array}{l}\text { Kualitas perairan } \\
\text { Water quality }\end{array}$ & $\begin{array}{l}\text { Kedalaman } \\
\text { Bathymetry }\end{array}$ & $\begin{array}{c}\text { Kecerahan } \\
\text { Water } \\
\text { transparency }\end{array}$ & $\begin{array}{c}\text { Suhu } \\
\text { Water } \\
\text { temperature }\end{array}$ & $\begin{array}{l}\text { Salinitas } \\
\text { Salinity }\end{array}$ & $\begin{array}{l}\text { Bobot } \\
\text { Weight }\end{array}$ \\
\hline $\begin{array}{l}\text { Kedalaman } \\
\text { Bathymetry }\end{array}$ & 1 & 1 & 2 & 3 & 0.36 \\
\hline $\begin{array}{l}\text { Kecerahan } \\
\text { Water transparency }\end{array}$ & 1 & 1 & $3 / 2$ & 2 & 0.30 \\
\hline $\begin{array}{l}\text { Suhu } \\
\text { Water temperature }\end{array}$ & $1 / 2$ & $2 / 3$ & 1 & 2 & 0.21 \\
\hline $\begin{array}{l}\text { Salinitas } \\
\text { Salinity }\end{array}$ & $1 / 3$ & $1 / 2$ & $1 / 2$ & 1 & 0.13 \\
\hline \multicolumn{6}{|c|}{ Rasio konsistensi (Consistency ratio): 0.013} \\
\hline $\begin{array}{l}\text { So sial-infrast rukt ur } \\
\text { Socio-infrast ruct ure }\end{array}$ & $\begin{array}{l}\text { Jarak ke } \\
\text { Distance to }\end{array}$ & $\begin{array}{l}\text { pemukiman } \\
\text { settlement }\end{array}$ & $\begin{array}{l}\text { Jarak ke mua } \\
\text { Distance to ri }\end{array}$ & $\begin{array}{l}\text { ra sungai } \\
\text { ver mouth }\end{array}$ & $\begin{array}{l}\text { Bobot } \\
\text { Weight }\end{array}$ \\
\hline $\begin{array}{l}\text { Jarak ke pemukiman } \\
\text { Distance to settlement }\end{array}$ & & 1 & $3 / 2$ & & 0.6 \\
\hline $\begin{array}{l}\text { Jarak ke muara sungai } \\
\text { Distance to river mouth }\end{array}$ & & $/ 3$ & 1 & & 0.4 \\
\hline \multicolumn{6}{|c|}{ Rasio konsistensi (Consistency ratio): 0.000} \\
\hline $\begin{array}{l}\text { Kelayakan lahan } \\
\text { Final suitability sites }\end{array}$ & $\begin{array}{r}\text { Kuali } \\
\text { Water }\end{array}$ & $\begin{array}{l}\text { tas air } \\
\text { quality }\end{array}$ & $\begin{array}{l}\text { Sosial-infra } \\
\text { Socio-infras }\end{array}$ & $\begin{array}{l}\text { st rukt ur } \\
\text { truct ure }\end{array}$ & $\begin{array}{l}\text { Bobot } \\
\text { Weight }\end{array}$ \\
\hline $\begin{array}{l}\text { Kualitas air } \\
\text { Water quality }\end{array}$ & & 1 & $3 / 4$ & & 0.43 \\
\hline $\begin{array}{l}\text { Sosial-infrastruktur } \\
\text { Socio-infrastructure }\end{array}$ & & /3 & 1 & & 0.57 \\
\hline \multicolumn{6}{|c|}{ Rasio konsistensi (Consistency ratio): 0.000} \\
\hline
\end{tabular}

laut dengan menggunakan keramba baik apung maupun tancap. Lokasi keramba apung yang cukup besar terdapat di Pulau Sirai. Kegiatan budidaya ikan di lokasi penelitian hanya merupakan tahapan pembesaran ikan, di mana benih ikan sebagian besar diperoleh dari hasil tangkapan di alam. Dibandingkan dengan budidaya ikan, budidaya rumput laut belum banyak berkembang. Hal ini terlihat dengan jelas, saat survai dilakukan tidak ditemukan adanya aktivitas budidaya rumput laut di lokasi penelitian. Adanya peningkatan jumlah rumah tangga perikanan (RTP) budidaya di Kecamatan Bintan Timur dari 110 RTP tahun 2005 menjadi 126 RTP tahun 2006
(Anonim, 2008), menunjukkan adanya peningkatan animo masyarakat untuk melakukan aktivitas budidaya laut.

Kegiatan budidaya rumput laut merupakan alternatif kegiatan budidaya laut yang dapat diimplementasikan di Kabupaten Bintan. Hal ini disebabkan kondisi lingkungan perairan yang mendukung, benih cukup tersedia karena dekat dengan pusat pengembangan rumput laut di Kabupaten Karimun (Anonim, 2008) serta dekat dengan pasar lokal maupun internasional. Di samping itu, sebagian masyarakat telah mempunyai pengalaman dalam membudidayakan rumput laut dengan skala kecil. 
Selain potensi yang dimiliki, teridentifikasi satu kendala dalam pengembangan budidaya laut di Kabupaten Bintan. Kendala utama kegiatan budidaya laut adalah adanya industri penambangan. Industri penambangan ini banyak ditemukan di pesisir timur Kecamatan Bintan Timur dan beberapa pulau di Kecamatan Mantang. Aktivitas penambangan ini, sangat berpengaruh terhadap kondisi kualitas perairan di antaranya tingkat kekeruhan (kecerahan) perairan. Kondisi ini secara tidak langsung akan berpengaruh terhadap biota yang dibudidayakan.

\section{Potensi Lahan Pengembangan Budidaya Rumput Laut}

Kondisi lingkungan perairan (meliputi suhu air, salinitas, kedalaman, dan kecerahan) di lokasi penelitian cukup mendukung kegiatan budidaya rumput laut (Gambar 3 dan Tabel 3). Secara umum kondisi kualitas perairan di lokasi penelitian masuk dalam kategori layak untuk pengembangan budidaya rumput laut. Hasil pengukuran suhu perairan menunjukkan hampir seluruhnya (95\%) masuk dalam kategori layak (Gambar 3a; Tabel 3). Salinitas perairan hampir seluruhnya (95\%) masuk dalam kategori tidak layak (Gambar 3b; Tabel 3). Hal ini disebabkan karena kisaran salinitas yang terukur di lokasi penelitian tergolong cukup tinggi dari prasyarat ideal kegiatan budidaya rumput laut. Rataan nilai salinitas yang terukur di lokasi penelitian adalah 35 , sedangkan kondisi ideal untuk budidaya rumput laut sekitar 32-34 (Tiensongrusmee, 1990; Mubarak et al., 1990). Kedalaman perairan sangat menentukan tipe dari media budidaya yang digunakan. Untuk metode apung, prasyarat kedalaman perairan yang ideal adalah sekitar 3-10 m (Tiensongrusmee, 1990). Tingkat kelayakan lahan dari aspek kedalaman perairan menunjukkan sangat mendukung, di mana sekitar $20 \%$ dari lokasi potensial masuk dalam

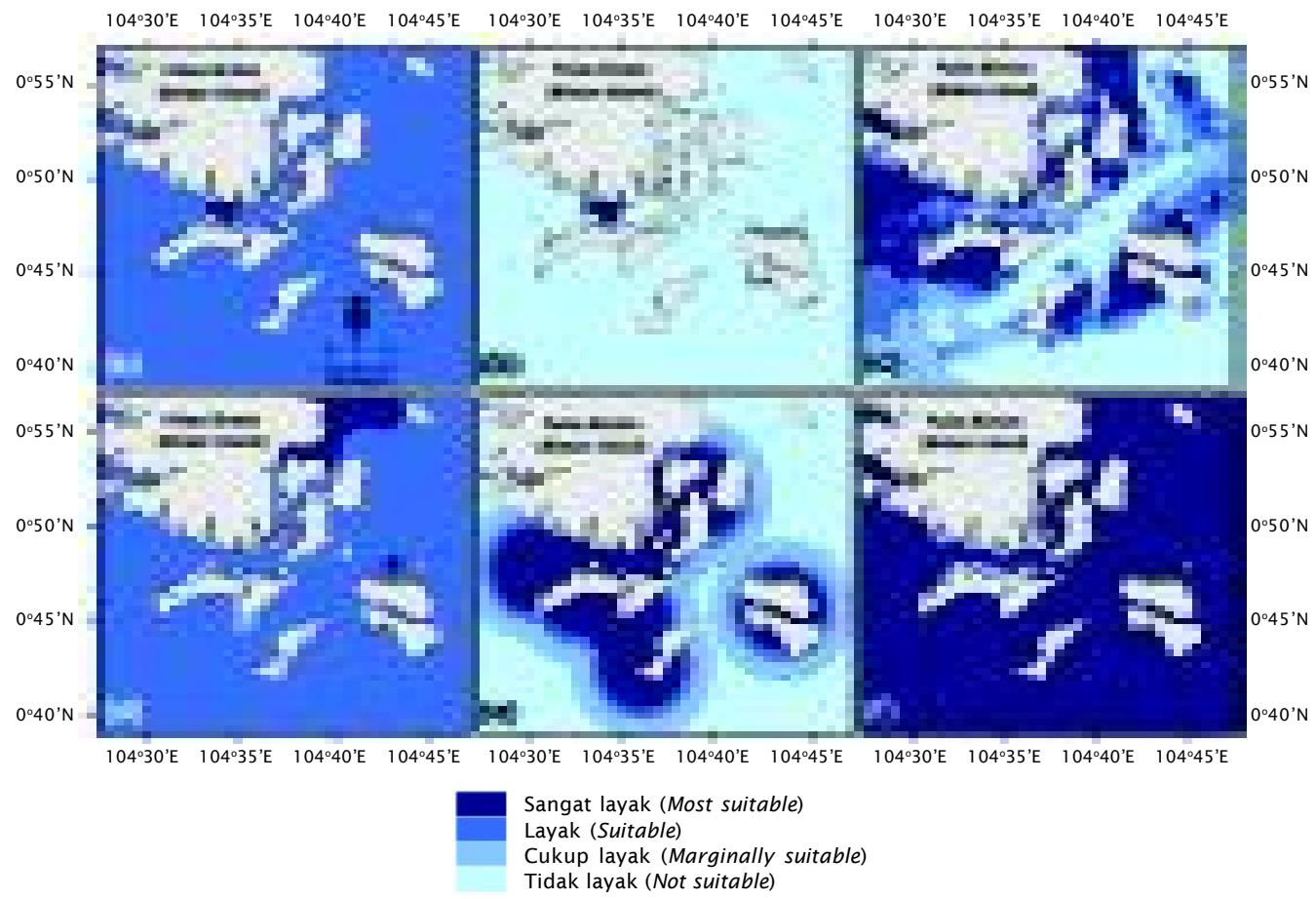

Gambar 3. Peta tingkat kelayakan lahan masing-masing parameter untuk budidaya rumput laut di Kabupaten Bintan: (a) suhu perairan, (b) salinitas, (c) kedalaman, (d) kecerahan, (e) jarak ke pemukiman, dan (f) jarak ke muara sungai

Figure 3. Suitability sites maps of each parameter for seaweed aquaculture in Bintan District: (a) water temperature, (b) salinity, (c) bathymetry, (d) water transparency, $(e)$ distance to settlement, and ( $f$ ) distance to river mouth 
Tabel 3. Persentase (\%) tingkat kelayakan lahan untuk budidaya rumput laut di Kabupaten Bintan. Luasan total lokasi penelitian adalah 904 km²

Table 3. Percentage (\%) of suitability sites for seaweed aquaculture in Bintan District. Total potential area is $904 \mathrm{~km}^{2}$

\begin{tabular}{|c|c|c|c|c|c|}
\hline $\begin{array}{c}\text { Peubah } \\
\text { Parameter }\end{array}$ & $\begin{array}{l}\text { Pembatas } \\
\text { Constraint }\end{array}$ & $\begin{array}{l}\text { Tidak } \\
\text { layak } \\
\text { Not } \\
\text { suitable }\end{array}$ & $\begin{array}{c}\text { Cukup } \\
\text { layak } \\
\text { Marginally } \\
\text { suitable }\end{array}$ & $\begin{array}{c}\text { Layak } \\
\text { Suitable }\end{array}$ & $\begin{array}{l}\text { Sangat } \\
\text { layak } \\
\text { Most } \\
\text { suitable }\end{array}$ \\
\hline Kualitas perairan & & & & & \\
\hline Water quality & 5.0 & 0.0 & 55.9 & 39.0 & 0.1 \\
\hline Suhu air & & & & & \\
\hline Water temperature & 5.0 & 0.0 & 0.0 & 94.8 & 0.2 \\
\hline $\begin{array}{l}\text { Salinitas } \\
\text { Salinity }\end{array}$ & 5.0 & 94.7 & 0.0 & 0.0 & 0.3 \\
\hline $\begin{array}{l}\text { Kedalaman } \\
\text { Bathymetry }\end{array}$ & 5.0 & 35.0 & 21.0 & 19.0 & 20.0 \\
\hline $\begin{array}{l}\text { Kecerahan } \\
\text { Water transparency }\end{array}$ & 5.0 & 0.0 & 0.6 & 90.4 & 4.0 \\
\hline $\begin{array}{l}\text { Sosial-infrastruktur } \\
\text { Socio-infrastructure }\end{array}$ & 5.0 & 0.1 & 45.0 & 31.9 & 18.0 \\
\hline $\begin{array}{l}\text { Jarak ke pe mukiman } \\
\text { Distance to settlement }\end{array}$ & 5.0 & 45.0 & 23.0 & 8.0 & 19.0 \\
\hline $\begin{array}{l}\text { Jarak ke muara sungai } \\
\text { Distance to river mouth }\end{array}$ & 5.0 & 0.2 & 0.4 & 0.4 & 94.0 \\
\hline $\begin{array}{l}\text { Final kelayakan lahan } \\
\text { Final suitability sites model }\end{array}$ & 5.0 & 0.0 & 45.0 & 37.0 & 13.0 \\
\hline
\end{tabular}

kategori sangat layak (Tabel 3). Lokasi tersebut tersebar di sekitar Pulau Mantang, Pulau Gin Kecil, Gin Besar, dan Pantai Timur Kecamatan Bintan Timur (Gambar 3c). Dari aspek kecerahan perairan, sekitar $90 \%$ dari total luasan penelitian masuk dalam kategori layak. Hanya $4 \%$ yang masuk dalam kategori sangat layak. Kondisi sangat layak ini ditemukan di bagian timur pesisir Kecamatan Bintan Timur (Gambar 3d). Rendahnya tingkat kelayakan lahan dari aspek kecerahan perairan disebabkan karena banyaknya kegiatan industri penambangan pasir sekitar pesisir pantai. Hal ini yang menyebabkan tingginya tingkat kekeruhan perairan. Kondisi yang sama juga telah dilaporkan oleh Radiarta et al. (2007) untuk kajian kelayakan rumput laut di Perairan Kecamatan Moro. Penggabungan seluruh parameter lingkungan menjadi submodel kualitas perairan menunjukkan bahwa lokasi yang sangat layak untuk pengembangan budidaya rumput laut ditemukan sangat kecil, $<1 \mathrm{~km}^{2}$ (Tabel 3). Umumnya submodel kualitas perairan masuk dalam kategori layak (39\%) dan cukup layak (56\%). Lokasi dengan kategori layak tersebar merata di perairan pulau-pulau kecil sekitar Pulau Bintan (Gambar 4a).

Dukungan sosial infrastruktur yang meliputi kawasan pemukiman dan muara sungai merupakan faktor yang dapat mempengaruhi kelangsungan budidaya rumput laut di lokasi penelitian. Terdapatnya daerah pemukiman akan mendukung kegiatan budidaya laut dalam hal penyediaan tenaga kerja dan pengawasan lahan budidaya yang ada (Luxton, 1999; Kingzet et al., 2002). Sebaliknya dengan adanya muara sungai akan berpengaruh terhadap pertumbuhan rumput laut yang dibudidayakan. Menurut Luxton (1999), pertumbuhan rumput laut (Eucheuma spp.) akan lambat pada wilayah sekitar muara sungai, disebabkan karena salinitas perairan 
yang rendah. Dari aspek jarak ke pemukiman, sekitar 19\% tergolong sangat layak untuk mendukung kegiatan budidaya rumput laut. Kategori sangat layak umumnya terkonsentrasi di pesisir Kecamatan Bintan Timur dan Mantang (Gambar 3e). Kategori sangat layak untuk aspek jarak ke muara sungai adalah 94\% (Tabel 3). Muara sungai yang ada umumnya terkonsentrasi di Pulau Bintan dan beberapa terdapat di Pulau Mantang (Gambar 3f). Dengan melihat karaktersitik sosial-infrastruktur yang ada di lokasi penelitian, kondisi ini cukup mendukung untuk kegiatan budidaya rumput laut di Kabupaten Bintan. Penggabungan seluruh parameter sosial-infrastruktur menjadi satu submodel menunjukkan bahwa kategori sangat layak ditemukan sebesar 18\% (Tabel 3). Lokasi dengan kategori sangat layak ini umumnya tersebar merata dengan konsentrasi di Kecamatan Bintan Timur dan Mantang (Gambar 4b).

Selain aspek pendukung kegiatan budidaya rumput laut yang meliputi kondisi kualitas perairan dan sosial-infrastruktur, terdapat juga aspek pembatas (constraint) yaitu kawasan industri (Gambar 1 dan 4c). Kegiatan industri yang umum ditemukan di lokasi penelitian adalah industri penambangan pasir. Kegiatan ini sangat mempengaruhi kondisi perairan di sekitar kawasan terutama pada aspek kecerahan (tingkat kekeruhan) perairan. Jika jarak sejauh $3 \mathrm{~km}$ ke lokasi industri dihitung, maka faktor pembatas ini memiliki luasan sekitar
$5 \%$ dari lokasi potensial budidaya rumput laut (Tabel 3). Daerah kawasan pembatas tersebut umumnya tersebar di Pulau Bintan (Gambar 4c). Untuk kajian kelayakan Iahan budidaya laut, faktor pembatas merupakan parameter penting yang harus dipertimbangkan. Parameter penting yang dapat dikategorikan sebagai pembatas kegiatan budidaya laut di antaranya ekosistem seagrass, pelabuhan kapal, kawasan industri dan kawasan pariwisata (Pérez et al., 2005; Radiarta et al., 2008).

Dengan menggabungkan seluruh submodel, akhirnya diperoleh klasifikasi kelayakan lahan untuk budidaya rumput laut di Kabupaten Bintan (Tabel 3 dan Gambar 5). Dari total luasan potensial untuk budidaya rumput laut (sekitar $904 \mathrm{~km}^{2}$ ), kategori sangat layak ditemukan sekitar $13 \%$. Kategori layak dan cukup layak masing-masing sebesar 37\% dan $45 \%$. Tidak ditemukan lokasi dengan kategori tidak layak bagi pengembangan budidaya rumput laut (Tabel 3). Lokasi dengan kategori sangat layak umumnya didukung oleh kondisi kualitas perairan yang baik dan sosialinfrastruktur yang memadai. Lokasi dengan kategori sangat layak terkonsentrasi di Pulau Mantang, Telang Kecil, Gin Besar, Numbing, Gin Kecil, Buton, Poto, dan Kelong (Gambar 5).

Kajian kelayakan lahan di penelitian ini telah menggabungkan berbagai parameter penting yang berpengaruh terhadap kegiatan budidaya rumput laut meliputi kualitas air

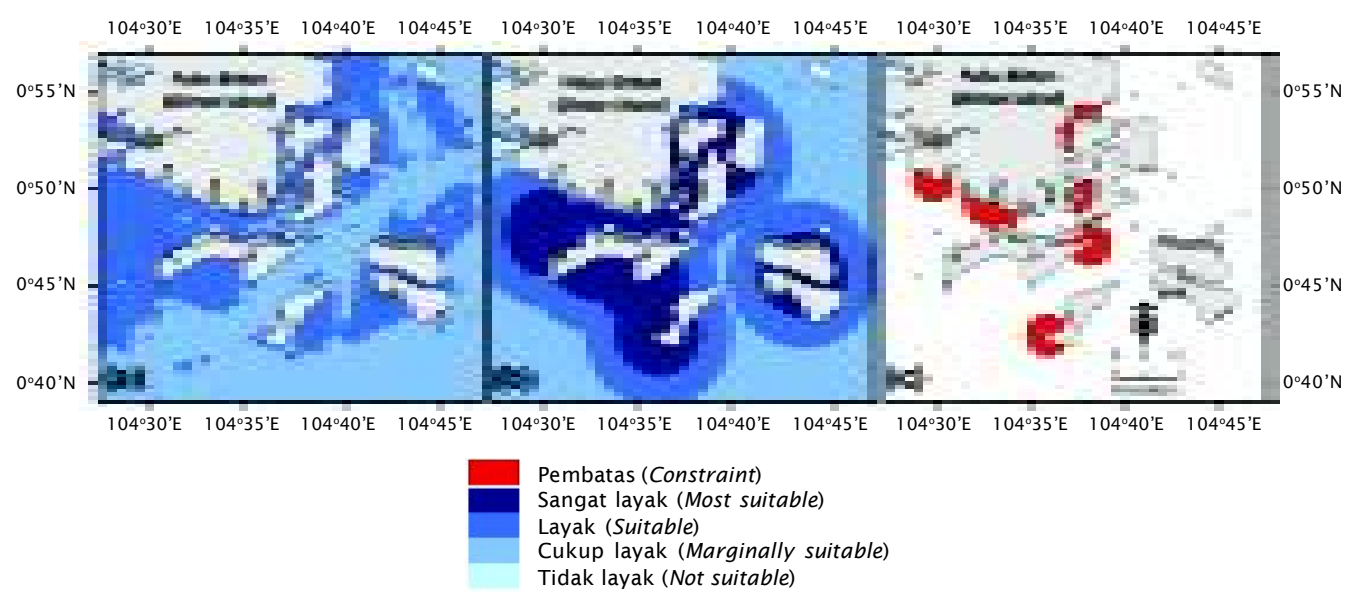

Gambar 4. Peta tingkat kelayakan lahan sub model kualitas perairan (a), sosial-infrastruktur (b), dan pembatas (c) untuk budidaya rumput laut di Kabupaten Bintan

Figure 4. Suitability sites maps of water quality sub-model (a), socio-infrastructure sub-model (b), and constraint (c) for seaweed aquaculture in Bintan District 


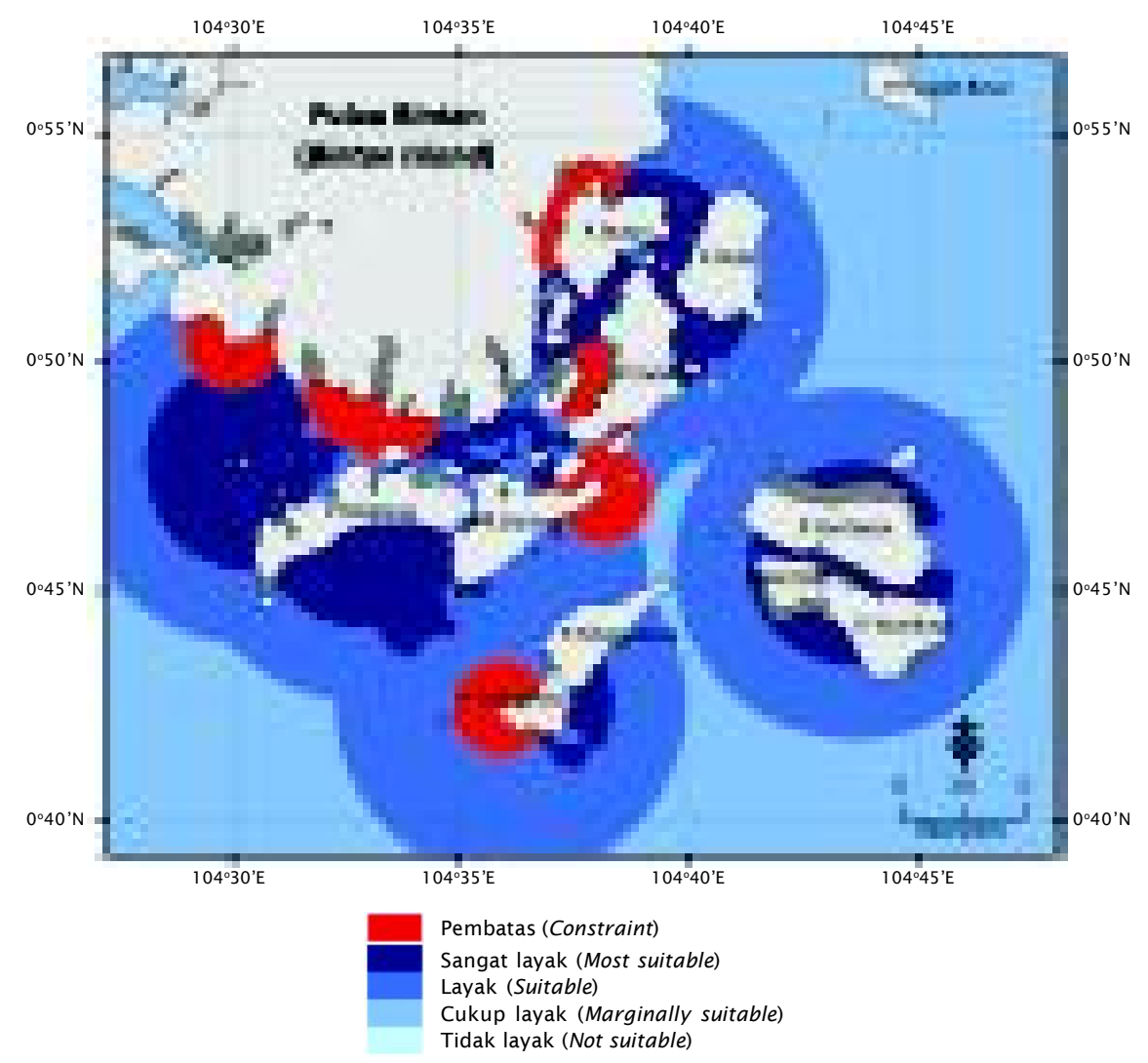

Gambar 5. Peta tingkat kelayakan lahan untuk budidaya rumput laut di Kabupaten Bintan Provinsi Kepulauan Riau

Figure 5. Overall site selection map for seaweed aquaculture in Bintan District Riau Island Province

dan sosial-infrastruktur. Hasil analisis dari penelitian ini dapat dipertajam lagi dengan menambahkan parameter penting lainnya baik dari aspek kualitas perairan (kecepatan arus, keterlindungan, dan tinggi gelombang), sosial ekonomi (aspek tata ruang dan pemasaran ketersediaan benih) maupun aspek infrastruktur (pengolahan produk dan ketersediaan benih). Menurut Kingzet et al. (2002), analisis kelayakan untuk budidaya laut harus memperhatikan dua kategori utama yaitu kondisi lingkungan perairan yang dapat mendukung pertumbuhan biota, serta kondisi sosialekonomi dan ketersediaan infrastruktur penunjang yang dapat mendukung kelangsungan kegiatan budidaya laut tersebut.

Analisis spasial yang diperoleh dari penelitian ini menunjukkan hasil yang sangat relevan dengan penetapan Kecamatan Bintan
Timur, Mantang, dan Bintan Pesisir di Kabupaten Bintan sebagai wilayah pengembangan minapolitan. Hasil analisis ini diharapkan dapat menjadi acuan bagi pengembangan budidaya rumput laut untuk mendukung kesuksesan program minapolitan di Kabupaten Bintan. Dalam implementasi pelaksanaan kegiatan budidaya rumput laut di lapangan, komunikasi dengan para pelaksana (stakeholder) perlu dimaksimalkan guna mendukung kegiatan budidaya rumput laut yang berkelanjutan (Stead et al., 2002).

\section{Aspek Klimatologi}

Kondisi klimatologi merupakan aspek penting lainnya yang perlu diperhatikan dalam pengembangan budidaya laut (Kapetsky, 2000). Kecepatan angin merupakan parameter klimatologi yang sering menjadi faktor penting 


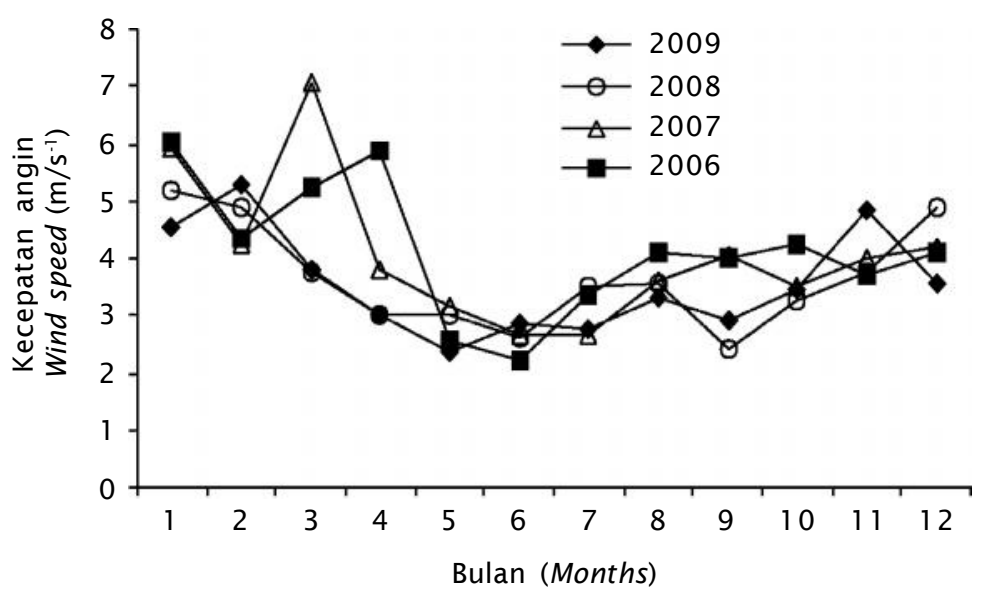

Gambar 6. Rata-rata kecepatan angin $\left(\mathrm{m} / \mathrm{s}^{-1}\right)$ bulanan dari tahun 20062009 di sekitar Pulau Bintan

Figure 6. Monthly average of wind speed $\left(\mathrm{m} / \mathrm{s}^{-1}\right)$ from 2006-2009 around Bintan Island

bagi kegiatan budidaya laut. Kecepatan angin dapat mempengaruhi kondisi gelombang dan arus permukaan, yang akhirnya secara tidak langsung dapat mempengaruhi media budidaya yang digunakan. Berdasarkan data kecepatan angin yang diperoleh dari stasiun pengamatan Tanjung Pinang $(0.917 \mathrm{LU}$; 104.533 BT; http://www.inigis.com/data-iklimdan-peta-hujan-indonesia/), menunjukkan bahwa kecepatan angin maksimum di lokasi penelitian terjadi sekitar bulan Februari-Maret (Gambar 6). Dengan tingginya kecepatan angin tersebut secara tidak langsung juga mempengaruhi kondisi kualitas perairan berupa tingginya tingkat kekeruhan perairan. Hasil diskusi dengan pembudidaya dan Dinas Kelautan dan Perikanan setempat menunjukkan bahwa pada musim tertentu tingkat kekeruhan menjadi sangat tinggi karena partikel lumpur tersebut terbawa oleh arus. Hal ini menjadi salah satu penghambat kegiatan budidaya laut (ikan) yang terdapat di lokasi penelitian.

\section{KESIMPULAN}

Kabupaten Bintan yang merupakan lokasi minapolitan telah menetapkan Kecamatan Bintan Timur, Mantang, dan Bintan Pesisir sebagai kawasan sentra pengembangan, dengan komoditas utama adalah rumput laut (Kappaphycus alvarezii). Hasil pengukuran lapangan menunjukkan bahwa kondisi kualitas perairan di Kabupaten Bintan masih dalam batas optimum untuk budidaya rumput laut. Analisis spasial dengan menggabung parameter kualitas perairan dan sosial-infrastruktur menunjukkan bahwa sekitar 13\% dari total potensial pengembangan $\left(904 \mathrm{~km}^{2}\right)$ masuk dalam kategori sangat layak. Lokasi dengan kategori sangat layak umumnya didukung oleh kondisi kualitas perairan yang baik dan sosialinfrastruktur yang memadai. Lokasi ini terkonsentrasi di Pulau Mantang, Telang Kecil, Gin Besar, Numbing, Gin Kecil, Buton, Poto, dan Kelong. Hasil dari penelitian ini menunjukkan luaran yang relevan dengan penetapan Kecamatan Bintan Timur, Mantang, dan Bintan Pesisir sebagai kawasan sentra pengembangan minapolitan. Analisis dari penelitian ini diharapkan dapat memberikan masukan kepada instansi terkait di Kabupaten Bintan guna mendukung pengembangan lebih lanjut program minapolitan.

\section{UCAPAN TERIMA KASIH}

Penulis mengucapkan terima kasih kepada Dinas Kelautan dan Perikanan Kabupaten Bintan atas bantuannya selama kegiatan lapangan. Penulis juga mengucapkan terima kasih kepada tim peneliti minapolitan Pusat Penelitian dan Pengembangan Perikanan Budidaya yang telah membantu kelancaran pengumpulan data lapangan di Kabupaten Bintan. Penelitian ini merupakan bagian dari penelitian minapolitan Pusat Penelitian dan Pengembangan Perikanan Budidaya T.A. 2010. 


\section{DAFTAR ACUAN}

Anonim. 2008. Laporan Akhir: identifikasi dan pemetaan pengembangan budidaya rumput laut di wilayah COREMAP II Kabupaten Bintan. Fakultas Perikanan dan IImu Kelautan, Universitas Riau, $183 \mathrm{hlm}$.

Aguilar-Manjarrez, J., Kapetsky, J.M., \& Soto, D. 2010. The potential of spatial planning tools to support the ecosystem approach to aquaculture.FAO/Rome. Expert Workshop. 19-21 November 2008, Rome, Italy. FAO Fisheries and Aquaculture Proceedings. No. 17. Rome, 176 pp.

Banai-Kashani, R. 1989. A new method for site suitability analysis: the analytic hierarchy process. Environmental Management, 13: 685-693.

Costa-Pierce, B. 2008. An ecosystem approach to marine aquaculture: a global review. In D. Soto, J. Aguilar-Manjarrez and N. Hishamunda (eds). Building an ecosystem approach to aquaculture. FAO Fisheries and Aquaculture Proceedings. No. 14. Rome, FAO, p. 81-155.

FAO Fisheries and Aquaculture Department. 2010. Global aquaculture production (online query). http://www.fao.org/figis/ servlet/TabSelector didownload tanggal 1 Desember 2010.

FAO. 2010 . Aquaculture development. 4. Ecosystem approach to aquaculture.FAO Technical Guidelines for Responsible Fisheries. No. 5, Suppl. 4.Rome, FAO, 53 pp.

Giap, D.H., Yi, Y., \& Yakupitiyage, A. 2005. GIS for land evaluation for shrimp farming in Haiphong of Vietnam. Ocean \& Coastal Management, 48: 51-63.

Johnson, K. \& McChow, J. 2001 . Using ArcGIS spatial analysis. Environmental Systems Research Institute (ESRI), Inc, USA, 236 pp.

Kapetsky, J.M. 2000. Present applications and future needs of meteorological and climatological data in inland fisheries and aquaculture. Aqricultural and Forest Meteorology, 103: 109-117.

Kingzet, B., Salmon, R., \& Canessa, R. 2002. First nations shellfish aquaculture regional business strategy. BC central and northern coast. Aboriginal relations and economic measures, Land and Water British Columbia Inc, $256 \mathrm{pp}$.

Luxton, D. 1999. Potential for eucheuma "cottonii" seaweed farming in Samoa. South Pacific Aquaculture Development
Project (Phase II) Food and Agriculture Organization of the United Nations (GCP/RAS/ 116/JPN). http://www.fao.org/docrep/ 005/AC888E/AC888E00.htm\#TOC disadur tanggal 1 Desember 2010.

Malczewski, J. 1999. GIS and mutlicriteria decision analysis. John Wiley \& Sons. New York, 392 pp.

Malczewski, J. 2000. On the use of weighted linear combination method in GIS: common and best practice approach. Transaction in GIS, 4: 5-22.

Morain, S. 1999. GIS solution in natural resources management: balancing the technical-political equation. On world press. USA, $361 \mathrm{pp}$.

Mubarak, H., Ilyas, S., Ismail, W., Wahyuni, I.S., Hartati, S.H., Pratiwi, E., xJangkaru, E., \& Arifuddin, R. 1990. Petunjuk teknis budidaya rumput laut. Badan Litbang Pertanian, Puslitbang Perikanan. IDRC, Infish, $93 \mathrm{hlm}$.

Nath, S.S., Bolte, J.P., Ross, L.G., \& AguilarManjarrez, J. 2000. Applications of geographical information systems (GIS) for spatial decision support in aquaculture. Aquacultural Engineering, 23: 233-278.

Pérez, O.M., Telfer, T.C., \& Ross, L.G. 2005. Geographical information system-based models for offshore floating marine fish cage aquaculture site selection in Tenerife, Canary Islands. Aquaculture Research, 36: 946-961.

Radiarta, I N., Prihadi, T.H., Saputra, A., Hariyadi, J., \& Johan, O. 2007. Penentuan lokasi budidaya rumput laut berdasarkan parameter lingkungan di perairan Kecamatan Moro, Provinsi Kepulauan Riau. J. Ris. Akuakultur, 2(3):319-328.

Radiarta, I N., Saitoh, S-I., \& Miyazono, A. 2008. GIS-based multi-criteria evaluation models for identifying suitable sites for Japanese scallop (Mizuhopecten yessoensis) aquaculture in Funka Bay, southwestern Hokkaido, Japan. Aquaculture, 284: 127135.

Saaty, T.L. 1977. A Scaling Method for Priorities in Hierarchical Structures. Journal of Mathematical Psychology, 15: 234-281.

Salam, M.A., Khatun, N.A., \& Ali, M.M. 2005. Carp farming potential in Barthatta Upazilla, Bangladesh: a GIS methodological perspective. Aquaculture, 245: 75-87.

Stead, S.M., Burnell, G., Goulletquer, P. 2002. Aquaculture and its role in integrated 
coastal zone management. Aquaculture International, 10: 447-468.

Sulistijo \& Nontji, A. 1995. Potensi lingkungan laut untuk kegiatan budidaya. Sudradjat et al. (penyunting). Prosiding temu usaha pemasyarakatan teknologi keramba jaring apung bagi budidaya laut, Jakarta 12-13 April 1995. Pusat Penelitian dan Pengembangan Perikanan, Badan Litbang Pertanian bekerjasama dengan Forum Komunikasi Penelitian dan Pengembangan Agribisnis, hlm. 54-68.

Tiensongrusmee, B. 1990. Site selection for Eucheuma spp. farming. UNDP/FAO Regional Seafarming Development and Demonstration Project (RAS/90/002).
Kasetsart University Campus, Bangkok, Thailand. http://www.fao.org/docrep/ field/003/AB738E/AB738E00.htm\#TOC disadur tanggal 30 November 2010.

Troell, M., Joyce, A., Chopin, T., Neoru, A., Bushmann, A.H., \& Fang, J-G. 2009. Ecological engineering in aquaculture-Potential for integrated multi-trophic aquaculture (IMTA) in marine offshore systems. Aquaculture, 297: 1-9.

Zang, J., Hansen, P.K., Fang, J., Wang, W., \& Jiang, Z. 2009. Assessment of the local environmental impact of intensive marine shellfish and seaweed farming-Application of the MOM system in the Sungo Bay, China. Aquaculture, 287: 304-310. 